\title{
PENGARUH SELF-EFFICACY, LINGKUNGAN KELUARGA, DAN LINGKUNGAN SEKOLAH TERHADAP MINAT BERWIRAUSAHA SISWA SMK JASA BOGA
}

\author{
Chomzana Kinta Marini \\ SMKN 1 Sewon \\ kintamarini@ymail.com \\ Siti Hamidah \\ Universitas Negeri Yogyakarta \\ hamidah_siti66@yahoo.com
}

\begin{abstract}
Abstrak
Penelitian ini bertujuan untuk: 1) memperoleh gambaran tentang self-efficacy, lingkungan keluarga, lingkungan sekolah, dan minat berwirausaha pada siswa SMK Jasa Boga; 2) mengetahui pengaruh self-efficacy, lingkungan keluarga, dan lingkungan sekolah baik secara sendiri-sendiri maupun bersama-sama terhadap minat berwirausaha siswa SMK Jasa Boga. Penelitian ini merupakan penelitian ex-post facto. Populasi penelitian adalah seluruh siswa SMK kelas XII Kompetensi Keahlian Jasa Boga se kota Yogyakarta. Teknik pengambilan sampel menggunakan proporsional random sampling. Teknik analisis data menggunakan analisis deskriptif, analisis regresi linier sederhana dan analisis regresi berganda. Hasil penelitian sebagai berikut. 1) Self-efficacy siswa sangat tinggi (mean 50,22); lingkungan keluarga siswa tinggi (mean 43,93); lingkungan sekolah tinggi (mean 44,72); dan minat berwirausaha siswa sangat tinggi (mean 47,25). 2) Terdapat pengaruh self-efficacy, lingkungan keluarga, dan lingkungan sekolah baik secara sendiri-sendiri maupun bersama-sama terhadap minat berwirausaha. Sumbangan efektif ketiga variabel bebas secara bersama-sama terhadap variabel terikatnya sebesar 39,35\%.
\end{abstract}

Kata Kunci: Self-Efficacy, Lingkungan Keluarga, Lingkungan Sekolah, Minat Berwirausaha

\section{THE EFFECTS OF SELF-EFFICACY, FAMILY ENVIRONMENT, AND SCHOOL ENVIRONMENT ON THE ENTREPRENEURIAL INTEREST OF THE CULINARY SERVICE DEPARTMENT STUDENTS AT VHSS}

\begin{abstract}
This study aims to: 1) describe self-efficacy, family environment, school environment, and entrepreneurial interest of students of the Culinary Service Department at vocational high schools (VHSs); and 2) investigate the effect of self-efficacy, family environment, school environment, both individually and as an aggregate on the entrepreneurial interest of grade XII students of the Culinary Service Department at VHSs. This was an ex post facto study. The research population comprised Grade XII students of the Culinary Service Department at VHSs in Yogyakarta. The sample, was selected by means of the proportional random sampling technique. The data were analyzed by means of the descriptive technique, simple linear regression, and multiple regression. The results of the study are as follows. 1) The students' self-efficacy is very high (mean 50.22), their family environment is high (mean 43.93), their school environment is high (mean 44.72), and their entrepreneurial interest is very high (mean 47.25). 2) There is a significant positive effect of self-efficacy, family environment ,school environment both individually and as an aggregate on the entrepreneurial interest. The effective contribution of the three independent variables as an aggregate to the dependent variable is $39.35 \%$.
\end{abstract}

Keywords: Self-efficacy, Family Environment, School Environment, Entrepreneurial Interest 


\section{PENDAHULUAN}

Semakin maju suatu negara, semakin banyak pula masyarakatnya yang terdidik yang memerlukan lapangan kerja sesuai kompetensinya. Namun demikian lapangan kerja yang tersedia tidak mencukupi, yang berakibat banyak orang terdidik yang menganggur, sehingga semakin dirasakan pentingnya dunia wirausaha (Arifin, 2008, p.1). Pembangunan akan lebih berhasil jika ditunjang oleh wirausahawan yang dapat membuka lapangan kerja karena kemampuan pemerintah sangat terbatas. Pemerintah tidak mampu menggarap semua aspek pembangunan karena sangat banyak membutuhkan anggaran belanja personalia dan pengawasan. Oleh sebab itu, wirausaha merupakan potensi pembangunan, baik dalam jumlah maupun dalam mutu wirausaha sendiri. Suatu kenyataan bahwa jumlah wirausahawan Indonesia masih sedikit dan mutunya belum bisa dikatakan hebat, sehingga persoalan pembangunan wirausaha Indonesia merupakan persoalan mendesak bagi suksesnya pembangunan.

Harapan pemerintah akan lahirnya wirausaha yang mampu mencetak lapangan kerja (job maker) nampaknya belum sepenuhnya terwujud. Hal ini nampak dari beberapa fakta tentang makin meningkatnya pengangguran dari waktu ke waktu, khususnya di Daerah Istimewa Yogyakarta. Kedaulatan Rakyat (6 April 2013,p.19), memuat data bahwa pengangguran di DIY mencapai 77.150 orang. Jumlah penduduk yang menganggur ini didominasi oleh angkatan muda produktif, usia 15-34 tahun, yaitu sebanyak $83 \%$. Menurut data BPS, angka pengangguran di tahun 2012 tersebut, lebih tinggi dibanding angka pengangguran di tahun 2011, yang tercatat sebanyak 74.317.

Data tersebut menunjukkan bahwa penganggur terbuka tingkat pendidikan SD sebanyak 7.447 orang, SMP 14.461 orang, SMA 16.148 orang, SMK 24.181 orang, Diploma 4.701 orang dan universitas 10.212 orang. Hasil survei Sakernas 2013 yang dilakukan kantor BPS Propinsi DIY sampai bulan Agustus menyebutkan, jumlah pengangguran di kota Yogyakarta, tahun 2012 tercatat 18.241 orang, dan pada tahun 2013 menjadi 17.217 orang. Lulusan SMA/SMK mencapai 14.961 orang dan sarjana 2.973 orang. Berdasarkan data diatas diketahui bahwa jumlah lulusan Sekolah Menengah Kejuruan (SMK) yang tidak terserap di dunia kerja atau menganggur, menduduki peringkat teratas.

Banyak alasan yang menjadi penyebab siswa SMK tidak mau membuka usaha sendiri ketika lulus sekolah, diantaranya adalah adanya pandangan bahwa menjadi pegawai (job seeker) lebih bergengsi daripada menjadi pencipta lapangan kerja (job maker), disamping banyak juga orang yang masih tidak mempertimbangkan wirausaha sebagai sebuah karir yang menjanjikan, tidak dimilikinya modal, maupun tidak dimilikinya keberanian mengambil resiko. Selain itu, alasan seseorang tidak membuka usaha sendiri adalah karena tidak adanya minat (Sugiono \& Isololipu, 2010, p.8).

Cara untuk menumbuhkan kesadaran berwirausaha diantaranya adalah dengan mengembangkan minat berwirausaha. Dengan minat yang ada pada siswa, maka siswa akan terdorong untuk mempelajari pengetahuan yang berkaitan dengan kewirausahaan lebih serius. Hal ini sebagaimana yang disampaikan oleh Munim (2006, p.1), bahwa semakin besar minat siswa untuk tertarik kepada bidang wirausaha, akan besar pula usaha dan keinginan siswa untuk mewujudkannya.

Minat tidak dibawa sejak lahir, namun minat tumbuh dan berkembang sesuai dengan faktor yang mempengaruhinya. Secara garis besar ada tiga faktor yang mempengaruhi minat, yaitu: faktor fisik, faktor psikis dan faktor lingkungan. Faktor fisik dapat menunjuk pada kesehatan seseorang yang diperlukan untuk menopang aktivitas berwirausaha. Faktor psikis meliputi: kepribadian (need of achievement, self efficacy), motif, perhatian dan perasaan. Sedangkan faktor lingkungan terdiri dari: lingkungan keluarga, lingkungan sekolah dan lingkungan masyarakat. Untuk membatasi masalah, maka pada kesempatan ini hanya diteliti self-efficacy, lingkungan keluarga dan lingkungan sekolah yang diduga besar pengaruhnya terhadap minat berwirausaha siswa.

Salah satu misi Sekolah Menengah Kejuruan (SMK) adalah mencetak lulusan yang siap untuk bekerja secara mandiri (berwirausaha). Dengan kata lain, dari SMK, diharapkan akan 
lahir calon wirausahawan, mengingat SMK memang diperuntukkan bagi peserta didik yang siap terjun menciptakan lapangan kerja baru. Namun harapan akan dikuasainya kemampuan berwirausaha pada lulusan SMK tersebut tampaknya belum dapat terwujud, karena mungkin selama ini pembelajaran di sekolah menengah kejuruan lebih mengutamakan bekal teknis melalui pembelajaran produktif, sementara bekal manajerial untuk peserta didik belum digali dengan maksimal. Kondisi ini dapat diamati dari rendahnya kemampuan peserta didik untuk menangkap peluang, keberanian untuk memulai usaha dan mengambil keputusan, lebih banyak yang menjadi pengikut, kurang kreatif dan rendah inisiatifnya.

Usaha bidang Jasa Boga adalah salah satu bidang wirausaha yang cukup potensial, karena usaha di bidang makanan atau kuliner adalah usaha yang menyangkut kebutuhan primer manusia. Apabila cukup jeli maka peluang untuk usaha bidang kuliner di Yogyakarta sangatlah besar, karena Yogyakarta adalah kota besar, kota pelajar, juga merupakan kota tujuan wisata. Disamping peluang, inspirasi dari usaha bidang kuliner sangat mudah diperoleh. Berdasarkan gambaran kesenjangan yang terjadi antara visi pendidikan SMK dengan realita keterserapan lulusan SMK dan berdasarkan keunggulan kota Yogyakarta di atas maka penelitian tentang pengaruh self-efficacy, lingkungan keluarga dan lingkungan sekolah terhadap minat berwirausaha siswa SMK Jasa Boga se kota Yogyakarta penting untuk dilakukan.

Penelitian ini bertujuan untuk: 1) memperoleh gambaran tentang self-efficacy, lingkungan keluarga, lingkungan sekolah, dan minat berwirausaha siswa SMK kelas XII Kompetensi Keahlian Jasa Boga se Kota Yogyakarta; 2) mengetahui pengaruh self-efficacy, lingkungan keluarga, lingkungan sekolah baik secara sendiri-sendiri atau bersama-sama terhadap minat berwirausaha, siswa SMK kelas XII Kompetensi Keahlian Jasa Boga se kota Yogyakarta.

\section{Self-efficacy}

\section{Pengertian Self-efficacy}

Self-efficacy merupakan penilaian seseorang terhadap dirinya sendiri atau tingkat keyakinan mengenai seberapa besar kemampuannya dalam mengerjakan suatu tugas tertentu untuk mencapai hasil tertentu (Woolfolk, 2007, p.332). Ada kalanya, seseorang tidak berkeinginan untuk melakukan sesuatu pekerjaan karena tidak memiliki keyakinan bahwa dirinya mampu dan akan berhasil melakukan hal tersebut. Padahal menurut Wilson, Kickul \& Marlino (2007, p.389) mengatakan bahwa self-efficacy merupakan salah satu diantara berbagai pengaruh kognitif sosial pada aspirasi karir anak-anak, dan self efficacy akademik memiliki efek langsung terkuat. Lebih lanjut self efficacy dinyatakan andal dalam memprediksi lingkup pilihan karir, kepentingan kerja, keuletan pada bidang yang sulit dan efektivitas pribadi.

\section{Pengaruh Usia pada Self-efficacy Remaja}

Menurut Bandura dalam Wilson, Kickul, \& Marlino (2007, p.401) ada beberapa faktor yang mempengaruhi self-efficacy, salah satu diantaranya adalah usia. Self-efficacy terbentuk melalui proses belajar sosial yang dapat berlangsung selama masa kehidupan. Individu yang lebih tua cenderung memiliki rentang waktu dan pengalaman yang lebih banyak dalam mengatasi suatu hal yang terjadi jika dibandingkan dengan individu yang lebih muda, yang mungkin masih memiliki sedikit pengalaman dan peristiwa-peristiwa dalam hidupnya. Individu yang lebih tua akan lebih mampu dalam mengatasi rintangan dalamhidupnya dibandingkan dengan individu yang lebih muda, hal ini juga berkaitan dengan pengalaman yang individu miliki sepanjang rentang kehidupannya. Fase-fase perkembangan self-efficacy dibedakan menjadi beberapa tahapan, sejak manusia dilahirkan, kemudian self-efficacy pada awal pertumbuhan, pada masa kanak-kanak, remaja, masa dewasa, hingga dalam usia lanjut. Siswa SMK adalah sekelompok remaja yang berusia 16-19 tahun. Pada masa ini, remaja akan belajar bagaimana menghadapi perubahan pubertas, menjalin hubungan secara emosional, serta tugas untuk memilih pekerjaan apa yang akan dikejar juga tampak dalam periode ini.

\section{Sumber-sumber Self-efficacy}

Woolfolk (2007, p.333) mengutip pendapat Bandura tentang sumber-sumber self-efficacy 
sebagai berikut: enactive mastery experiences, physiological and emotional arousal, vicarious experiences, and verbal persuasion.

Enactive mastery experience adalah pengalaman keberhasilan \& pencapaian prestasi, yang merupakan sumber informasi self-efficacy yang paling berpengaruh. Berdasarkan pengalaman masa lalu terlihat bukti apakah seseorang mengarahkan seluruh kemampuannya untuk meraih keberhasilan. Umpan balik terhadap hasil kerja seseorang yang positif akan meningkatkan kepercayaan diri seseorang. Kegagalan pada berbagai pengalaman hidup dapat di atasi dengan upaya tertentu dan dapat memicu persepsi self-efficacy menjadi lebih baik karena membuat individu tersebut mampu untuk mengatasi rintangan-rintangan yang lebih sulit nantinya.

Physiological and emotional arousal (keadaan fisiologis dan psikologis) maksudnya seseorang percaya bahwa sebagian tanda-tanda psikologis menghasilkan informasi dalam menilai kemampuannya. Kondisi stress dan kecemasan dilihat individu sebagai tanda yang mengancam ketidakmampuan diri. Level of arousal dapat memberikan informasi mengenai tingkat self-efficacy tergantung bagaimana arousal itu diinterpretasikan. Bagaimana seseorang menghadapi suatu tugas, apakah cemas atau khawatir (self-efficacy rendah) atau tertarik (selfefficacy tinggi) dapat memberikan informasi mengenai self-efficacy orang tersebut. Dalam menilai kemampuannya seseorang dipengaruhi oleh informasi tentang keadaan fisiknya untuk menghadapi situasi tertentu dengan memperhatikan keadaan fisiologisnya.

Vicarious experience (Pengalaman orang lain) merupakan cara meningkatkan self-efficacy dari pengalaman keberhasilan yang telah ditunjukkan oleh orang lain. Ketika melihat orang lain dengan kemampuan yang sama berhasil dalam suatu bidang/tugas melalui usaha yang tekun, individu juga akan merasa yakin bahwa dirinya juga dapat berhasil dalam bidang tersebut dengan usaha yang sama. Sebaliknya self-efficacy dapat turun ketika orang yang diamati gagal walapun telah berusaha dengan keras. Individu juga akan ragu untuk berhasil dalam bidang tersebut. Peran vicarious experience terhadap self-efficacy seseorang sangat dipengaruhi oleh persepsi diri individu tersebut tentang dirinya memiliki kesamaan dengan model. Semakin seseorang merasa dirinya mirip dengan model, maka kesuksesan dan kegagalan model akan semakin mempengaruhi self-efficacy. Sebaliknya apabila individu merasa dirinya semakin berbeda dengan model, maka self-efficacy menjadi semakin tidak dipengaruhi oleh perilaku model. Seseorang akan berusaha mencari model yang memiliki kompetensi atau kemampuan yang sesuai dengan keinginannya. Dengan mengamati perilaku dan cara berfikir model tersebut akan dapat memberi pengetahuan dan pelajaran tentang strategi dalam menghadapi berbagai tuntutan lingkungan.

Adapun verbal persuasion (persuasi verbal), digunakan secara luas untuk membujuk seseorang bahwa mereka mempunyai kemampuan untuk mencapai tujuan yang mereka cari. Orang yang mendapat persuasi secara verbal maka mereka memiliki kemauan untuk menyelesaikan tugas-tugas yang diberikan akan mengerahkan usaha yang lebih besar daripada orang yang tidak dipersuasi bahwa dirinya mampu pada bidang tersebut.

Self-efficacy dibedakan atas tiga dimensi, yaitu: Level/magnitude, generallity dan strength. Masing-masing dimensi mempunyai impilikasi penting dalam performansi (Zimmerman, 2000, p.83).

Level/magnitude, yaitu penilaian kemampuan individu pada tugas yang sedang dihadapinya. Dimensi ini mengacu pada tingkat kesulitan suatu masalah yang dipersepsikan berbeda dari masing-masing individu. Ada yang menganggap masalah itu sulit ada juga yang menganggap masalah itu mudah untuk dilakukan. Apabila individu merasa sedikit rintangan yang dihadapi maka masalah tersebut mudah ditangani. Dengan kata lain magnitude adalah masalah yang berkaitan dengan derajat kesulitan tugas individu. Komponen ini berimplikasi pada pemilihan perilaku yang akan dicoba individu berdasar ekspektasi efikasi pada tingkat kesulitan tugas. Individu akan berupaya melakukan tugas tertentu yang ia persepsikan dapat dilaksanakannya dan ia akan menghindari situasi dan perilaku yang ia persepsikan di luar batas kemampuannya. Zimmerman (2000, p.83) mengatakan level terbagi atas 3 bagian yaitu : 1) analisis pilihan 
perilaku yang akan dicoba, yaitu seberapa besar individu merasa mampu atau yakin untuk berhasil menyelesaikan tugas dengan pilihan perilaku yang akan diambil; 2) menghindari situasi dan perilaku yang dirasa melampaui batas kemampuannya; dan 3) menyesuaikan dan menghadapi langsung tugas-tugas yang sulit.

Pengertian generality, mengacu pada penilaian efficacy individu berdasarkan aktivitas keseluruhan tugas yang pernah dijalaninya. Jadi generality berkaitan dengan tingkah laku dimana individu merasa yakin terhadap kemampuannya. Individu dapat merasa yakin terhadap kemampuan dirinya, tergantung pemahaman kemampuan dirinya yang terbatas pada suatu aktivitas dan situasi tertentu atau pada serangkaian aktivitas dan situasi yang lebih luas dan bervariasi. Jadi generality dapat dikatakan sebagai keyakinan siswa terhadap kemampuan yang dimiliki dalam menggeneralisasikan tugas-tugasnya, berdasarkan tugas yang pernah dijalaninya.

Adapun yang dimaksud strength, mengacu pada ketahanan dan keuletan individu dalam menyelesaikan masalah. Individu yang memiliki keyakinan yang kuat terhadap kemampuannya untuk menyelesaikan masalah akan terus bertahan dalam usahanya meskipun banyak kesulitan dan tantangan. Dengan efikasi diri, kekuatan untuk usaha yang lebih besar mampu didapat. Semakin kuat perasaan efikasi diri dan semakin besar ketekunan, maka semakin tinggi kemungkinan kegiatan yang dipilih dan dilakukan dengan berhasil. Pengharapan yang kuat dan mantap pada individu akan mendorong untuk gigih dalam berupaya mencapai tujuan, walaupun mungkin belum memiliki pengalaman-pengalaman yang menunjang. Sebaliknya, pengharapan yang lemah dan raguragu terhadap kemampuan diri, akan mudah digoyahkan oleh pengalaman-pengalaman yang tidak menunjang. Jadi yang dimaksud strength adalah taraf keyakinan siswa terhadap kemampuan yang dimilikinya, dalam mengatasi masalah yang muncul dari penyelesaian tugastugasnya.

\section{Lingkungan Keluarga}

Keluarga merupakan lingkungan sosial terdekat dari seorang wirausaha, yang sangat besar peranannya dalam membentuk karakter, termasuk karakter wirausaha dari seorang anak. Saroni (2012) mengatakan bahwa lingkungan keluarga mempunyai andil yang sangat besar dalam mempersiapkan anak-anak menjadi seorang wirausahawan di masa yang akan datang. Keluargalah yang mula-mula bertanggung jawab atas pendidikan anak-anak, sehingga keluarga dapat dikatakan sebagai peletak dasar bagi pola perilaku serta perkembangan pribadi anak. Lingkungan keluarga dapat menjadi lingkungan yang kondusif untuk melatih dan mengasah karakter kewirausahaan, yang dapat menjadi bekal pada anak untuk mulai mengarahkan minatnya kelak kemudian hari. Pada lingkungan keluarga tersebut, seorang anak mendapat inspirasi dan dukungan berwirausaha dari keluarga, dan terdapat kegiatan dalam keluarga tersebut yang bermakna belajar kewirausahaan.

\section{Inspirasi dan Dukungan Berwirausaha}

Hisrich, Peters \& Shepherd (2008, p.65) mengatakan bahwa hubungan orang tua secara keseluruhan dengan anak, terlepas dari apakah orang tuanya pengusaha, maupun tidak, mungkin yang merupakan aspek paling penting dari lingkungan keluarga anak adalah dalam membangun keinginan untuk aktivitas kewirausahaan dalam individu. Orang tua pengusaha harus mendukung dan mendorong kemandirian, prestasi, dan tanggung jawab.

Inspirasi untuk berwirausaha dapat diberikan langsung oleh orang tua, atau dapat juga melalui model yang dihadirkan orang tua. Misalnya dengan menceritakan kisah wirausahawan sukses kepada anak. Dukungan untuk berwirausaha dapat berupa dukungan moril (kesempatan, kepercayaan, pemberian ide/pemikiran), atau dukungan materiil dengan memberikan modal, penyediaan alat/ perlengkapan usaha atau lokasi/tempat usaha.

\section{Belajar Kewirausahaan dalam Keluarga}

Patel (2007, p.23) mengatakan bahwa anak-anak telah memiliki tanggung jawab dalam keluarga yang besar sejak masih kecil dan telah diberi peluang untuk berperan dan terlibat dalam kegiatan kewirausahaan yang ada dalam keluarga. Hal ini terjadi antara lain karena desakan kebutuhan finansial keluarga, 
namun orang tua dapat sekaligus memberi kesempatan kepada anak-anak untuk mengembangkan ketrampilan dan belajar untuk menerima dan memahami tanggung jawab. Situasi seperti ini akan membekali anak dengan ketrampilan, pola pikir, keyakian dan nilai-nilai yang diperlukan untuk menjadi pengusaha yang sukses, serta memiliki pengaruh pada perkembangan karakteristik psikologis kewirausahaan individu sejak usia dini.

\section{Lingkungan Sekolah}

Sarifudin (2011) menyampaikan bahwa pendidikan (sekolah) menjadi salah satu institusi yang mempunyai peranan penting dalam upaya melahirkan wirausaha yang tangguh. Sekolah diharapkan dapat mentransformasi karakteristik wirausaha kepada siswanya. Selain melalui pembelajaran kewirausahaan, lingkungan sekolah yang kondusif akan mendorong tumbuhnya minat berwirausaha.

Lingkungan sekolah yaitu lingkungan sosial (guru \& tenaga kependidikan, teman-teman sekolah \& budaya sekolah) dan lingkungan non sosial (kurikulum, program dan sarana prasarana) dalam lembaga pendidikan formal yang memberikan dukungan terhadap pembentukan jiwa kewirausahaan dan pengembangan potensi kewirausahaan peserta didik.

\section{Guru dan Tenaga Kependidikan}

Guru sangat mempengaruhi pembentukan pribadi anak didik, dan dapat membuatnya menjadi calon entrepreneur Mulyani, dkk (2010, p.63) menyampaikan bahwa keteladanan adalah perilaku dan sikap guru maupun tenaga kependidikan yang lain dalam memberi contoh terhadap tindakan-tindakan yang baik, sehingga nantinya menjadi panutan bagi peserta didik. Jika menghendaki agar peserta didik berperilaku dan bersikap sesuai dengan nilainilai kewirausahaan, maka guru dan tenaga kependidikan harus menjadi orang yang pertama dan utama memberikan contoh mengenai hal tersebut. Misalnya datang di kantor tepat pada waktunya, bekerja keras, jujur.

\section{Teman-teman Sekolah}

Teman sekelas atau teman sekolah, dapat mempengaruhi minat siswa untuk berwirausaha Aditya Putra (2012, p.3) mengatakan bahwa dorongan teman cukup berpengaruh terhadap semangat berwirausaha karena kita dapat berdiskusi dengan bebas dibandingkan dengan orang lain. Teman biasa memberi dorongan, pengertian, bahkan bantuan.

\section{Budaya Sekolah}

Upaya menumbuhkan jiwa wirausaha melalui budaya sekolah tersebut dilakukan dengan cara memasukkan nilai-nilai karakteristik wirausaha ke dalam peraturan yang berlaku di sekolah. Peraturan tersebut meliputi : tata tertib siswa, kode etik guru \& karyawan, serta perarturan lain yang mengatur setiap orang yang sedang berada di lingkungan.

\section{Kurikulum}

Kurikulum adalah a plan for learning yang merupakan unsur substansial dalam pendidikan. Tanpa kurikulum kegiatan belajar mengajar tidak dapat berlangsung, sebab materi yang akan disampaikan guru harus diprogramkan terlebih dahulu (Bahri, 2008, p.180). Dalam upaya mencetak lulusan sebagai calon wirausahawan, maka keberpihakan kurikulum harus tanpak nyata baik dalam strukturnya maupun dalam implementasinya.

\section{Program}

Program mengundang wirausahawan sebagai nara sumber, merupakan salah satu program yang mendukung pembelajaran kewirausahaan di sekolah. Sarifudin (2011) memaparkan bahwa membuka wawasan berwirausaha dapat dilakukan melalui kegiatan seperti : ceramah, diskusi, mengundang lulusan SMK yang berhasil, mengundang wirausahawan yang berada di sekitar sekolah agar menceritakan keberhasilan dan kegagalan yang pernah mereka alami atau mengunjungi perusahaan, melalui pengamatan langsung dengan pemagangan atau studi banding (http://aniesmedia.blogspot.com/2011/04/membangun-jiwa-wirausaha-siswa-smk.html/2013/9/26).

\section{Sarana Prasarana}

Sarana dan fasilitas, merupakan salah satu komponen lingkungan non sosial di sekolah, yang sangat potensial untuk mendorong pengembangan minat dari peserta didik. Sarana dan fasilitas tersebut antara lain berupa koperasi sekolah dan unit produksi. 
Koperasi sekolah berfungsi sebagai sarana pendidikan dalam upaya melatih kemampuan entrepreneurship siswa. Melalui koperasi sekolah, siswa dapat mengembangkan ketrampilan wirausaha seperti pembukuan pelayanan pelanggan dan aktifitas wirausaha lainnya. Selain itu, siswa juga dilatih untuk memiliki rasa tanggung jawab, semangat dan disiplin yang tinggi (http://www.aviva.co.id /id /index. php?option $=$ com_content\&view $=$ article $\& \mathrm{id}=2$ 39:koperasi-sekolah-sarana-pembentukan -jiwa-entrepreneurshipsiswa\&catid $=83 \&$ Itemid $=741$ \&lang $=\mathrm{en} / 2013 / 9 / 26$ ).

Keberadaan unit produksi yang lengkap sarana dan prasarananya dalam sebuah sekolah, khususnya SMK, sangat diperlukan untuk wahana berlatih berwirausaha bagi para siswa.

Jati Sidi (2001, p.116) mengatakan bahwa penggalakan Unit Produksi adalah merupakan salah satu jalan mewirausahakan SMK. Hasil Unit Produksi selain dapat dimanfaatkan untuk bermacam-macam kegunaan, misalnya untuk meningkatkan kesejahteraan warganya, memperbaiki dan meremajakan fasilitas sekolah, mendekatkan relevansi program kejuruan dengan kebutuhan dunia usaha/industri, dan yang lebih penting adalah menyiapkan siswa berlatih kerja secara nyata dan bertanggung jawab, karena hasilnya akan dijual di pasaran umum.

\section{Minat Berwirausaha}

\section{Pengertian Minat Berwirausaha}

Slameto dalam Djaali (2007, p.121) mengatakan bahwa minat adalah rasa lebih suka dan rasa keterikatan pada suatu hal atau aktivitas, tanpa ada yang menyuruh. Minat pada dasarnya merupakan penerimaan akan suatu hubungan antara diri sendiri dengan sesuatu di luar diri. Pengertian minat juga disampaikan Winkel \& Srihastuti (2004, p.650), yaitu kecenderungan yang agak menetap pada seseorang untuk merasa tertarik pada suatu bidang tertentu, dan merasa senang berkecimpung dalam berbagai kegiatan yang berkaitan dengan bidang itu.

Kewirausahaan adalah tindakan kreatif manusia yang membuat sesuatu yang tidak berharga (tidak mempunyai nilai), menjadi berharga. Kewirausahaan menciptakan suatu kesempatan tanpa adanya bekal sumber daya sebe- lumnya atau menciptakan kesempatan dengan sumber daya yang masih sangat kurang. Kewirausahaan memerlukan visi, tekad dan komitmen untuk memimpin orang lain dalam upaya mewujudkan visi tersebut. Kewirausahaan juga mempunyai keberanian untuk mengambil resiko yang telah diperhitungkan sebelumnya (Lambing \& Kuehl, 2000, p.14). Berdasarkan pengertian tersebut, maka yang dimaksud dengan berwirausaha adalah tindakan yang kreatif, untuk menciptakan sesuatu yang tidak mempunyai nilai menjadi berharga, dengan bekerja keras, mandiri, berani mengambil resiko, maupun menghadapi tantangan.

Jadi minat berwirausaha adalah keinginan, keingintahuan, ketertarikan, serta kesediaan dari siswa SMK Jasa Boga untuk bekerja keras, mandiri, berani mengambil resiko maupun menghadapi tantangan dalam keterbatasan, dengan bertindak kreatif guna memenuhi kebutuhan hidupnya serta kemajuan usahanya.

\section{METODE PENELITIAN}

\section{Jenis Penelitian}

Penelitian ini termasuk dalam penelitian ex-post facto, karena dalam penelitian ini hanya mengungkapkan gejala yang terjadi seperti apa adanya serta mengungkapkan faktor-faktor yang berpengaruh dari variabel bebas terhadap variabel terikat. Penelitian ini merupakan penelitian deskriptif korelasional dengan pendekatan kuantitatif.

\section{Waktu dan Tempat Penelitian}

Penelitian ini dilakukan bulan Maret 2014 sampai dengan bulan Mei 2014. Lokasi penelitian yaitu SMK Kompetensi Keahlian Jasa Boga, yang ada di kota Yogyakarta, yaitu SMKN 6 Yogyakarta, SMKN 4 Yogyakarta, dan SMK BOPKRI Yogyakarta.

\section{Subyek Penelitian}

Populasi dalam penelitian ini adalah seluruh siswa kelas XII Kompetensi Keahlian Jasa Boga, dari semua SMK yang ada kota Yogyakarta sebanyak 271 siswa. Teknik pengambilan sampel menggunakan proportionale random sampling, dimana masing-masing sekolah dengan jumlah responden yang berbeda akan di- 


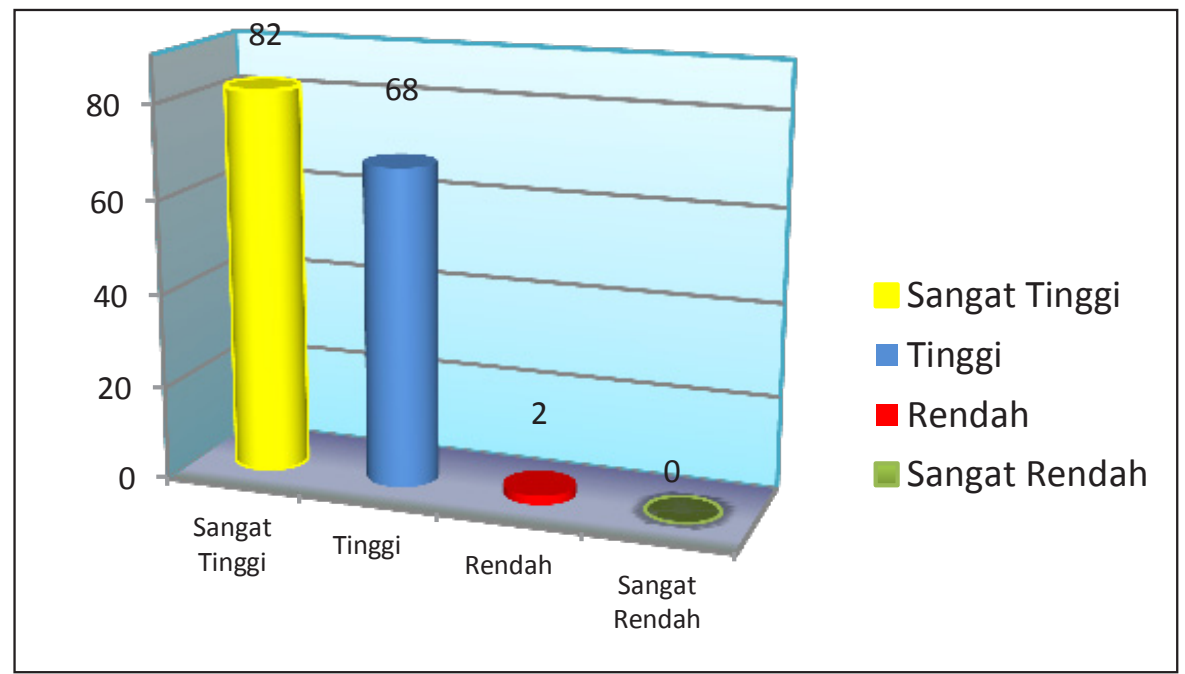

Gambar 1. Histogram Frekuensi Variabel Self Efficacy

ambil sampelnya berdasarkan proporsi jumlah responden pada masing-masing sekolah tersebut (Sugiyono, 2009, p.118). Sampel dalam penelitian ini berjumlah 152 siswa. Penentuan jumlah sampel berdasarkan tabel Isaac dan Michael pada taraf kesalahan 5\%.

\section{Teknik Pengumpulan Data dan Teknik Analisis Data}

Teknik pengumpulan data dalam penelitian ini menggunakan angket tertutup. Uji validitas menggunakan validitas isi dan validitas konstruk (construct validity). Uji reliabilitas menggunakan rumus Alpha Cronbach. Instrumen dapat dikatakan reliabel jika koefesien $\mathrm{Al}$ pha Cronbach lebih besar dari 0,70 (Mardapi, 2008, p.125). Teknik analisis data menggunakan analisis deskriptif, analisis regresi linier sederhana dan analisis regresi berganda.

\section{HASIL PENELITIAN DAN PEMBAHASAN}

Hasil analisis data self-efficacy menunjukkan terdapat sebanyak 82 siswa $(53,9 \%)$ pada kategori sangat tinggi; sebanyak 68 siswa (44,7\%) pada kategori tinggi; dan sebanyak 2 siswa $(1,3 \%)$ pada kategori rendah; dan tidak ada siswa yang termasuk pada kategori sangat rendah. Nilai mean $(50,22)$ hasil analisis deskriptif dibandingkan dengan distribusi kategori, maka mean self-efficacy terletak pada rentang nilai sangat tinggi. Dengan demikian dinyatakan bahwa self-efficacy siswa SMK
Kompetensi Keahlian Jasa Boga di Kota Yogyakarta termasuk dalam kategori sangat tinggi. Berikut hasil analisis data digambarkan melalui histogram frekuensi yang dapat dilihat pada gambar 1 .

Kecenderungan self-efficacy yang sangat tinggi dari siswa SMK Jasa Boga mengandung arti bahwa siswa telah memiliki keyakinan yang sangat tinggi akan kemampuannya dalam melaksanakan tugas-tugas yang sulit dalam berwirausaha, memiliki keyakinan yang sangat tinggi akan kekuatan dan ketahanan menghadapi masalah dalam berwirausaha dan dan siswa juga memiliki keyakinan yang sangat tinggi pula terhadap kemampuannya mengerjakan tugas dalam berwirausaha yang beragam. Hal ini sebagaimana pendapat Bandura dalam Woolfolk (2007: p.128) mengutarakan bahwa karakteristik individu yang memiliki self-efficacy yang tinggi adalah ketika individu tersebut merasa yakin bahwa mereka mampu menangani secara efektif peristiwa dan situasi yang mereka hadapi, tekun dalam menyelesaikan tugas-tugas, percaya pada kemampuan diri yang mereka miliki, memandang kesulitan sebagai tantangan bukan ancaman dan suka mencari situasi baru, menetapkan sendiri tujuan yang menantang dan meningkatkan komitmen yang kuat terhadap dirinya, menanamkan usaha yang kuat dalam apa yang dilakukanya dan meningkatkan usaha saat menghadapi kegagalan, berfokus pada tugas dan memikirkan strategi dalam menghadapi kesulitan, cepat 


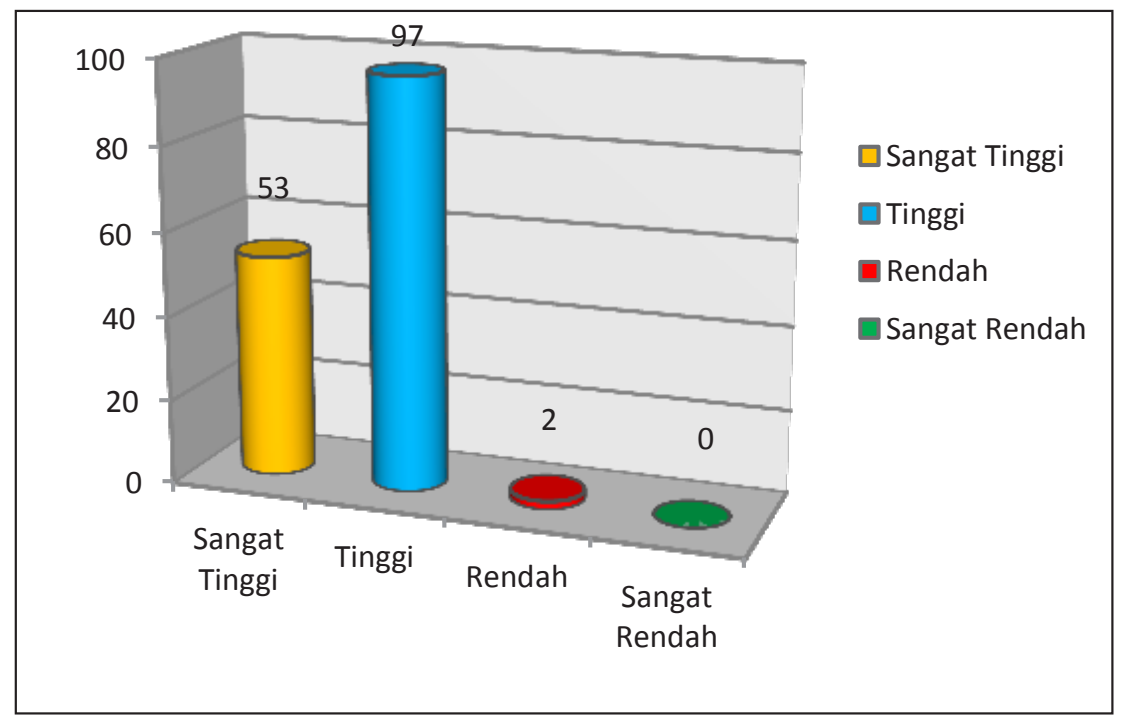

Gambar 2. Histogram Frekuensi Variabel Lingkungan Keluarga

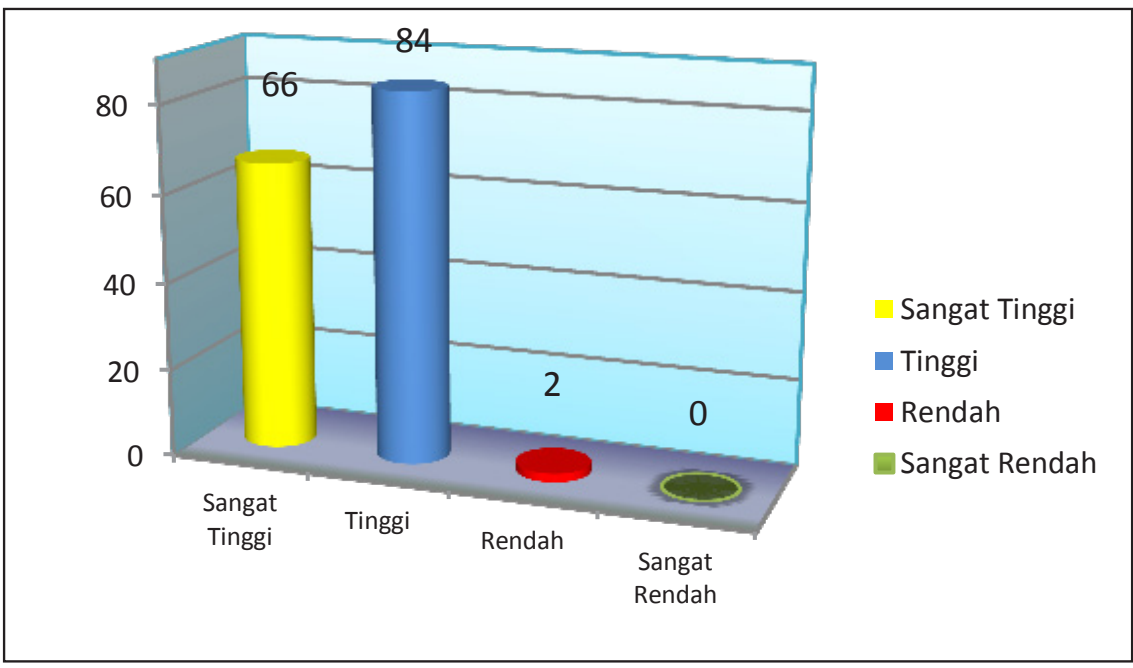

Gambar 3. Histogram Frekuensi Variabel Lingkungan Sekolah

memulihkan rasa mampu setelah mengalami kegagalan, dan menghadapi stressor atau ancaman dengan keyakinan bahwa mereka mampu mengontrolnya.

Hasil analisis data lingkungan keluarga menunjukkan terdapat sebanyak 53 siswa $(34,9 \%)$ pada kategori sangat tinggi; sebanyak 97 siswa $(63,8 \%)$ pada kategori tinggi; dan sebanyak 2 siswa $(1,3 \%)$ pada kategori rendah; dan tidak ada siswa yang termasuk pada kategori sangat rendah. Nilai mean $(43,93)$ hasil analisis deskriptif dibandingkan dengan distribusi kategori, maka mean lingkungan keluarga terletak pada rentang nilai tinggi. Jadi dapat dinyatakan bahwa lingkungan keluarga siswa
SMK kelas XII Kompetensi Keahlian Jasa Boga di Kota Yogyakarta termasuk dalam kategori tinggi. Berikut hasil analisis data digambarkan melalui histogram frekuensi yang dapat dilihat pada gambar 2 .

Kecenderungan lingkungan keluarga yang tinggi dari siswa SMK Jasa Boga mengandung arti bahwa keluarga siswa terutama orang tua telah memberikan inspirasi dan dukungan untuk berwirausaha kepada siswa. Dukungan tersebut antara lain berupa pemberian kesempatan untuk berlatih berwirausaha, pemberian modal, penyiapan fasilitas, teladan dan penanaman jiwa kewirausahaan. Selain itu aktivitas dalam keluarga siswa yang berlangsung terus- 


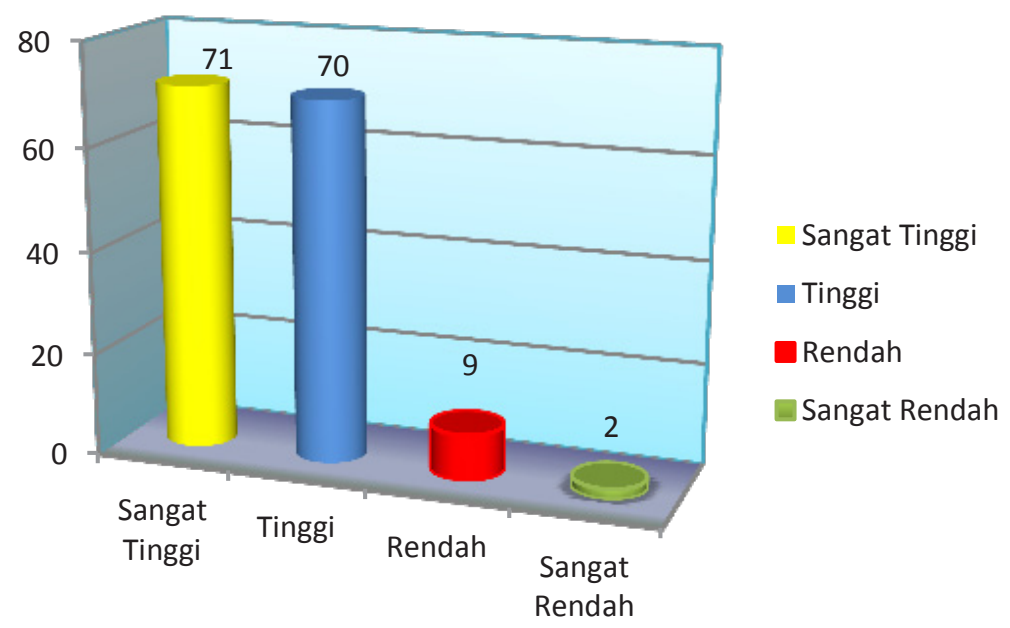

Gambar 4. Histogram Frekuensi Variabel Lingkungan Sekolah

menerus dapat dimaknai sebagai belajar berwirausaha oleh siswa yang didukung oleh orang tuanya, baik dalam rangka meningkatkan ketrampilan teknis berwirausaha maupun sebagai wahana penanaman jiwa wirausaha siswa.

Hasil analisis data lingkungan sekolah menunjukkan terdapat sebanyak 66 siswa $(43,4 \%)$ pada kategori sangat tinggi; sebanyak 84 siswa $(55,3 \%)$ pada kategori tinggi; dan sebanyak 2 siswa $(1,3 \%)$ pada kategori rendah; dan tidak ada siswa yang termasuk pada kategori sangat rendah. Nilai mean $(44,72)$ hasil analisis deskriptif dibandingkan dengan distribusi kategori, maka mean lingkungan sekolah terletak pada rentang nilai tinggi. Dengan demikian dapat dinyatakan bahwa lingkungan sekolah pada siswa SMK kelas XII Kompetensi Keahlian Jasa Boga di Kota Yogyakarta termasuk dalam kategori tinggi. Berikut hasil analisis data digambarkan melalui histogram frekuensi yang dapat dilihat pada gambar 3 .

Kecenderungan lingkungan sekolah yang tinggi dari siswa SMK Jasa Boga mengandung arti bahwa guru \& tenaga kependidikan, teman-teman sekolah \& budaya yang ada di sekolah menjalankan perannya dengan baik dalam menanamkan jiwa kewirausahaan pada peserta didik. Selain itu kurikulum, program dan sarana prasarana pada SMK jurusan Jasa Boga di kota Yogyakarta tinggi peranannya pengembangan potensi kewirausahaan peserta didik.
Sedangkan dari hasil analisis data minat berwirausaha menunjukkan terdapat sebanyak 71 siswa $(46,7 \%)$ pada kategori sangat tinggi; sebanyak 70 siswa $(46,1 \%)$ pada kategori tinggi; dan sebanyak 9 siswa $(5,9 \%)$ pada kategori rendah; dan 2 siswa (1,3\%) siswa yang termasuk pada kategori sangat rendah. Nilai mean $(47,25)$ hasil analisis deskriptif dibandingkan dengan distribusi kategori terletak pada rentang nilai tinggi. Dengan demikian dapat dinyatakan bahwa minat berwirausaha siswa SMK kelas XII Kompetensi Keahlian Jasa Boga di Kota Yogyakarta termasuk dalam kategori sangat tinggi. Berikut hasil analisis data digambarkan melalui histogram frekuensi yang dapat dilihat pada gambar 4 .

Kecenderungan minat berwirausaha yang sangat tinggi dari siswa SMK Jasa Boga mengandung arti bahwa siswa SMK kelas XII Kompetensi Keahlian Jasa Boga di kota Yogyakarta memiliki keingintahuan tentang kewirausahaan, ketertarikan terhadap kewirausahaan dan kesediaan untuk berwirausaha yang sangat tinggi.

Hasil uji hipotesis kesatu dengan analisis regresi sederhana menunjukkan bahwa variabel self-efficacy berpengaruh positif terhadap minat berwirausaha siswa SMK kelas XII Kompetensi Keahlian Jasa Boga di Kota Yogyakarta. Hal ini dapat dibaca dari hasil analisis data bahwa nilai signifikansi sebesar $0,000<$ 0,05 pada taraf signifikansi $5 \%$. Hasil analisis 
juga menunjukkan bahwa nilai koefisien korelasi (r) bernilai positif, yaitu sebesar 0,440 , sehingga dapat dinyatakan bahwa variabel selfefficacy berpengaruh positif terhadap minat berwirausaha siswa SMK kelas XII Kompetensi Keahlian Jasa Boga di kota Yogyakarta.

Kenyataan yang tampak pada hasil penelitian tidaklah menyimpang dari teori yaitu self-efficacy selalu berhubungan dan berdampak pada pemilihan perilaku individu termasuk pemilihan karir sebagai wirausahawan yang bermula dari minat berwirausaha. Ada kalanya, siswa SMK yang sudah dibekali ilmu dan ketrampilan yang memadai, tidak berkeinginan untuk berwirausaha karena tidak memiliki keyakinan bahwa dirinya mampu dan akan berhasil melakukan hal tersebut. Siswa ini tidak memiliki self-efficacy. Narasi ini sejalan dengan pendapat Wilson, Kickul \& Marlino $(2007$, p.389) yaitu konsep self-efficacy telah banyak digunakan dalam literatur teori karir untuk menjelaskan pilihan karir yang dirasakan, menyatakan preferensi/pilihan karir, dan akhirnya, perilaku yang berorientasi pada karier.

Hasil uji hipotesis kedua dengan analisis regresi sederhana menunjukkan bahwa variabel lingkungan keluarga berpengaruh positif terhadap minat berwirausaha siswa SMK kelas XII Kompetensi Keahlian Jasa Boga di Kota Yogyakarta. Hal ini dapat dibaca dari hasil analisis data bahwa nilai signifikansi sebesar $0,000<$ 0,05 pada taraf signifikansi $5 \%$. Hasil analisis juga menunjukkan bahwa nilai koefisien korelasi (r) bernilai positif, yaitu sebesar 0,461 , sehingga dapat dinyatakan bahwa variabel Lingkungan Keluarga berpengaruh positif terhadap minat berwirausaha siswa SMK kelas XII Kompetensi Keahlian Jasa Boga di kota Yogyakarta. Hal ini sejalan dengan penelitian yang dilakukan Aprilianty yang berjudul, "Pengaruh Kepribadian Wirausaha, Pengetahuan Kewirausahaan, dan Lingkungan, terhadap Minat Berwirausaha Siswa SMK", menunjukkan bahwa potensi kepribadian wirausaha memberi pengaruh cukup berarti terhadap minat berwirausaha $(27,3 \%)$, pengetahuan kewirausahaan berpengaruh berarti terhadap minat berwirausaha $(13,7 \%)$, lingkungan keluarga memberi pengaruh yang berarti terhadap minat berwirausaha $(22 \%)$.
Keluarga merupakan lingkungan sosial terdekat dari seorang wirausaha, yang sangat besar peranannya dalam membentuk karakter, termasuk karakter wirausaha dari seorang anak. Berkaitan dengan pengaruh lingkungan keluarga terhadap minat berwirausaha anakanak, McClelland dalam Lupiyoadi (2007, p.12) mengatakan bahwa lingkungan keluarga dapat menjadi lingkungan yang kondusif untuk melatih dan mengasah karakter kewirausahaan, yang dapat menjadi bekal pada anak untuk mulai mengarahkan minatnya kelak kemudian hari.

Hasil uji hipotesis ketiga dengan analisis regresi sederhana menunjukkan bahwa variabel lingkungan sekolah berpengaruh positif terhadap minat berwirausaha siswa SMK kelas XII Kompetensi Keahlian Jasa Boga di Kota Yogyakarta. Hal ini dapat dibaca dari hasil analisis data bahwa nilai signifikansi sebesar $0,000<$ 0,05 pada taraf signifikansi $5 \%$. Hasil analisis juga menunjukkan bahwa nilai koefisien korelasi (r) bernilai positif, yaitu sebesar 0,563 , sehingga dapat dinyatakan bahwa variabel Lingkungan Sekolah berpengaruh positif terhadap minat berwirausaha siswa SMK kelas XII Kompetensi Keahlian Jasa Boga di kota Yogyakarta.

Pendidikan (sekolah) menjadi salah satu institusi yang mempunyai peranan penting dalam upaya melahirkan wirausaha yang tangguh. Sekolah diharapkan dapat mentransformasi karakteristik wirausaha kepada siswanya. Terlebih di Sekolah Menengah Kejuruan (SMK), yang mempunyai tujuan utama yaitu menghasilkan tamatan yang siap memasuki lapangan kerja, baik secara mandiri maupun bekerja pada orang lain. Arikunto (2002, p.104) mengatakan bahwa minat dan perhatian manusia dipengaruhi antara lain oleh lingkungan. Lingkungan tersebut dapat berupa lingkungan keluarga maupun lingkungan sekolah. Adapun lingkungan sekolah yang kondusif untuk menumbuhkan minat siswa adalah : bahan pelajaran yang menarik minat, alat-alat pelajaran, situasi kelas yang menarik, bahkan gurunya sendiri.

Hasil analisis regresi berganda menunjukkan bahwa variabel self-efficacy, lingkungan keluarga dan lingkungan sekolah berpen- 
garuh positif secara bersama-sama terhadap minat berwirausaha siswa SMK kelas XII Kompetensi Keahlian Jasa Boga di kota Yogyakarta. Hal ini dapat dibaca dari hasil uji $\mathrm{F}$ yang menunjukkan nilai sebesar 32,012 . Jika dibandingkan dengan nilai sebesar 2,665 pada taraf signifikansi 5\%, maka nilai . Hasil analisis juga menunjukkan bahwa nilai koefisien korelasi (r) bernilai positif, yaitu sebesar 0,627, sehingga dapat dinyatakan bahwa variabel selfefficacy, lingkungan keluarga dan lingkungan sekolah berpengaruh positif terhadap minat berwirausaha siswa SMK kelas XII Kompetensi Keahlian Jasa Boga di kota Yogyakarta.

\section{SIMPULAN DAN SARAN}

\section{Simpulan}

Gambaran dari variabel-variabel yang diteliti dari siswa SMK kelas XII Kompetensi Keahlian Jasa Boga di kota Yogyakarta adalah sebagai berikut: self-efficacy termasuk kategori sangat tinggi, Nilai mean yang diperoleh 50,22 sehingga terdapat $43,42 \%$ siswa yang berada di atas skor rerata, dan $56,58 \%$ berada di bawah skor rerata; lingkungan keluarga termasuk kategori tinggi, nilai mean yang diperoleh 43,93 sehingga $50,66 \%$ siswa yang berada di atas skor rerata, sedang 49,34\% siswa berada di bawah skor rerata; Lingkungan sekolah siswa termasuk kategori tinggi, nilai mean yang diperoleh 44,72 , sehingga terdapat $51,32 \%$ siswa yang berada di atas skor rerata, sedang $48,68 \%$ siswa berada di bawah skor rerata; dan minat berwirausaha siswa termasuk kategori sangat tinggi, nilai mean yang diperoleh 47,25 , sehingga terdapat $48,68 \%$ siswa yang berada di atas skor rerata, sedang $51,32 \%$ siswa berada di bawah skor rerata.

Berdasarkan hasil uji hipotesis dapat disimpulkan sebagai berkut: terdapat pengaruh positif dan signifikan self-efficacy terhadap minat berwirausaha, dengan nilai koefisien korelasi ( $\mathrm{rx}_{1} \mathrm{y}$ ) adalah 0,440 dan $\mathrm{p}<0,05$; terdapat pengaruh positif dan signifikan lingkungan keluarga terhadap minat berwirausaha, dengan nilai koefisien korelasi $\left(\mathrm{rx}_{2} \mathrm{y}\right)$ adalah 0,461 dan $\mathrm{p}<0,05$; terdapat pengaruh positif dan signifikan lingkungan sekolah terhadap minat berwirausaha, dengan nilai koefisien korelasi $\left(\mathrm{r}_{\mathrm{x} 3} \mathrm{y}\right)$ adalah 0,563 dan $p<0,05$; dan terdapat pengaruh positif dan signifikan secara bersama-sama dari self-efficacy, lingkungan keluarga, dan lingkungan sekolah, terhadap minat berwirausaha siswa, dengan nilai koefisien korelasi $\left(\mathrm{r}_{\mathrm{x} 1, \times 2, \times 3} \mathrm{y}\right)$ adalah 0,627 . Kuatnya pengaruh variabel selfefficacy, lingkungan keluarga dan lingkungan sekolah terhadap minat berwirausaha ditunjukkan oleh besarnya nilai koefisien determinasi yaitu 0,394 . Dengan demikian dapat dikatakan sumbangan efektif ketiga variabel bebas terhadap minat berwirausaha siswa adalah sebesar $39,4 \%$.

\section{Saran}

Keluarga hendaknya meningkatkan perannya dalam mendidik anaknya, melalui sinergi yang dibangun dengan pihak sekolah. Dalam hal ini, sekolah dapat mengambil inisiatif untuk memberikan informasi kepada orang tua bila menjumpai siswa yang memiliki minat dan bakat berwirausaha. Selanjutnya, sekolah dapat memberikan arahan kepada orang tua dalam bentuk rekomendasi pengasuhan agar pendidikan di rumah dapat lebih bermakna dan terarah guna meningkatkan minat dan kesiapan siswa mencapai cita-citanya untuk berwirausaha. Bila perlu sekolah dapat memberi masukan kepada orang tua cara memberi inspirasi usaha pada anak maupun dukungan riil yang dapat dilakukan orang tua, agar anak dapat mulai merintis usaha di rumah.

Untuk mendekatkan calon alumni pada pencapaian cita-citanya berwirausaha, sekaligus dalam rangka mendampingi alumni untuk merintis usaha, sekolah dapat mendirikan semacam Lembaga Konsultasi Wirausaha, dengan kegiatan konsultasi usaha, pelatihan, akses permodalan, dan lain-lain.

\section{DAFTAR PUSTAKA}

Aditia, Rano. 2012. Faktor-faktor penentu minat mahasiswa manajemen untuk berwirausaha (studi mahasiswa Manajemen FE UN Padang). Jurnal Manajemen, Volume 01, Nomor 01, September 2012

Arifin. (2008). Menumbuhkan minat berwirausaha. Diambil pada 20/5/2013, dari http://akseskomputer.blogspot.com 
/2008/08/menumbuhkkan-minat-berwirausaha.html

Badan Pusat Statistik, Yogyakarta 2013

Bahri, Syaiful. (2008). Psikologi belajar. Edisi II. Jakarta: PT Rineka Cipta

Djaali. (2007). Psikologi pendidikan. Jakarta: Bumi Aksara

Hisrich, R.D., Peters, M.P., \& Stepeherd, D.A. (2008). Entrepreneurship. New York: The McGraw Hill Irwin

Jati Sidi, Indra. (2001). Menuju masyarakat belajar. Menggagas pradigma baru pendidikan. Jakarta: PT Logos Wacana Ilmu

Kedaulatan Rakyat, Sabtu Kliwon, 6 April 2013, hal 19, Liputan Khusus.

Lambing,P., Kuehl,C.R. (2000). Entrepreneurship. Upper Saddle River: Prentice Hall.

Mulyani, Endang, dkk. (2010). Pengembangan pendidikan kewirausahaa, bahan pelatihan penguatan metodologi pembelajaran berdasarkan nilai-nilai budaya untuk membentuk daya saing dan karakter bangsa. Jakarta: Kemdiknas BP2 PusKur

Munim, Ahmad. (2006). Hubungan prestasi belajar kewirausahaan dengan minat berwiraswasta. Diambil pada 6/9/2006, dari http:// www.smkn1samarinda. net $/ ? \mathrm{p}=$ artikel\&data $=00000000011$

Patel, K. (2007). Understanding the Influence of Famili context on entrepreneurial characteristics, Gordon Institute of Business Science: Universitas of Pretoria.
Sarifudin, Anis . (2011). Membangun jiwa wirausaha siswa SMK. Diakses 26/9 2013 dari http://aniesmedia.blogspot. com/2011/04/membangun-jiwa-wirausaha-siswa-smk.html

Saroni. (2012). Lingkungan belajar. Diakses pada 29/11/2013 dari http:/hendri ansdia mond.blogspot.com/2012/01/lingkungan-belajar-html

Sugiono, Arif \& Isololipu, Kurnianing. (2010). Berani hidup kaya, jurus jitu menjadi entrepreneur andal. Jakarta: Pustaka Timur.

Sugiyono. (2009). Metode penelitian pendidikan, pendekatan kuantitatif, kualitatif, dan $R \& D$. Bandung: Alfabeta

Wilson, F., Kickul, J., Marlino, D. (2007). Gender, entrepreneurial self efficacy, and entrepreneurial career intentions: implication for entrepreneurship education. Journal ETP (Entrepreneurship, Theory \& Practice, Boston: Baylor University

Winkel, WS \& Srihastuti, M.M. (2004). Bimbingan dan konseling di Institusi Pendidikan. Yogyakarta: Media Abadi

Woolfolk, Anita, (2007). Educational psychology (Tenth Eddition).United States of America: Pearson Education, Inc.

Zimmerman, B.J. 2000. Self-efficacy: an essential motive to learn. Journal Contemporary Educational Psychology 25, 82-91. USA: Graduate School and University Center of City University of New York 